\section{The Model M Method and Its Contribution to a Socially Responsible Society}

\author{
Anita Hrast \\ IRDO - Institute for the Development of Social Responsibility, Slovenia \\ anita.hrast@irdo.si

\section{Matjaž Mulej} \\ University of Maribor, Faculty of Economics and Business, Slovenia \\ IRDO - Institute for the Development of Social Responsibility, Slovenia \\ Establishing president of IASCSY - International Academy for Systems and \\ Cybernetic Sciences \\ matjaz.mulej@um.si
}

\begin{abstract}
Model $M$ means being young and being a role model for others in finding innovative employment or creating one's own employment, and thus becoming and remaining an active citizen. In years 2012-2018, IRDO - Institute for the Development of Social Responsibility - implemented the project Model M Slovenia. The project started in the Podravje region, in years 2012-2014, with a small amount of money invested by the local community (The City Municipality of Maribor). Later (in years 2016-2018), it became a nation-wide Slovenian project funded by the EU's Social Fund and the Republic of Slovenia. The purpose of the project was to empower youth with training, networking, counselling and active participation in the society to create their own models of success. In this paper, we present the Model $\mathrm{M}$ method (MMm) that we have developed through the Model M Slovenia project and its social impact on the employment of youth in Slovenia. With the Social Return on Investment (SROI), a method for social impact measurement, we present how the funds invested in the local pilot project were later multiplied tenfold on a national level within the project Model M Slovenia. The originality of the MMm, as presented in this paper, is in its requisitely holistic approach to youth training in terms of personal and social responsibility. The MMm is accelerating the (self)employment of youth and other unemployed persons. The MMm was created by a team of business practitioners and social responsibility researchers. Their aim was to practice and develop social responsibility, interdependence and requisitely holistic approach as a systemic behaviour, suggested by the global humankind in the ISO 26000 guidance standard.
\end{abstract}

Keywords: project Model M, youth, employment, social return on investment, impact measurement, social responsibility, socially responsible society
ORIGINAL SCIENTIFIC PAPER

RECEIVED: JANUARY 2019

REVISED: JANUARY 2020

ACCEPTED: FEBRUARY 2020

DOI: 10.2478/ngoe-2020-0003

UDK: 331-053.6:316.62:159.947.23

JEL: M54, 035, J64, M53, I31

Citation: Hrast, A., \& Mulej, M.

(2020). The Model M Method and Its Contribution to a Socially Responsible Society. Naše gospodarstvo/Our Economy, 66(1), 23-38. DOI: 10.2478/ ngoe-2020-0003

\section{NG OE}

\section{NAŠE GOSPODARSTVO OUR ECONOMY}

\begin{tabular}{l|l|l} 
Vol. 66 No. 12020 \\
\hline
\end{tabular}

pp. $23-38$ 


\section{Introduction}

The global socioeconomic crisis broke out in 2008 and, at that time, humanity announced to the highest global authorities: humans must activate social responsibility as a way out of the crisis (ISO, 2010). The ISO 26000 guidance standard for social responsibility provides all life practices, summarized in seven topics and with their essence expressed under three items (ISO, 2010):

(1) Everyone's responsibility for influencing people and nature,

(2) Interdependence,

(3) Holistic approach.

In ISO 26000, social responsibility is supported by seven principles that match the required characteristics of people and organizations.

Social responsibility always and everywhere prevents many problems and costs. Most literature on social responsibility deals with organizations, not with society (Collins, 2005; Medvedeva \& Umpleby, 2015; Bohinc, 2017). A review of the Slovenian and international literature and lessons learned about the given practice has shown that neither Slovenia nor the rest of the world yet have the political economy of a socially responsible society. The first step in this direction is the book by M. Mulej et al. (2019).

According to the OECD Economic Survey for Slovenia, an EU Member State, in 2017 (OECD, 2017), its economy is experiencing a strong recovery after a prolonged period of low growth following the international financial and domestic banking crises. The current economic prosperity reflects a combination of recent structural reforms, business restructuring, supportive monetary conditions and improved export markets. The downsides include unemployment consisting increasingly of low-skilled and older workers who are unable to fill in the emerging labour shortages. In addition, long-run growth prospects are hindered by a rapidly ageing population and low productivity growth, partly linked to product market issues. The OECD 2017 Survey makes key policy recommendations to secure fiscal sustainability through pension and health care reform. In addition, the Survey recommends measures to enhance economic growth by boosting investment incentives in human and physical capital. Such investments will improve the skills and adaptability of the Slovenian workforce and promote competitive organizations, fostering faster productivity growth and higher living standards for all Slovenians by ensuring more inclusive growth. This includes young people with degrees and poor knowledge about finding or generating their jobs.

The youth unemployment rate (OECD, 2019) is the number of unemployed 15-24-year-olds expressed as a percentage of the youth labour force. Unemployed people are those who report that they have no jobs, seek jobs and have taken active steps to find a job in the last four weeks. In Slovenia, this rate was $8.8 \%$ in 2018 (15.3\% in 2016) of youth labour force, and $15.2 \%$ in EU (28 countries) (18.7\% in 2016). According to these figures, Slovenia worked well on supporting projects and programmes for reducing youth unemployment.

The Model M Slovenia project with its Model M method (MMm) refers to a holistic approach to reduce youth unemployment. It makes an interesting contribution to the development of a socially responsible society by supporting and raising the employment capability of young people with degrees and no jobs. The MMm is a practical outcome of fifteen years of efforts made by IRDO - Institute for the Development of Social Responsibility - including 14 international conferences and over 20 books with contributions by over 1000 authors from around the world (IRDO, 2018). The main purpose of the paper is to present the method that we have created through the Model M Slovenia project called Model M method.

The research presented here describes how this project, as one of the EU supported projects in Slovenia, helped young people find their jobs faster and the impact of this approach on the society.

The research questions were: (1) What kind of holistic approach could help young people become (self-)employed as soon as possible? and (2) What could be the new method for reducing youth unemployment?

In our research, we analize the case of the Model M Slovenia project (Hrast et al, 2015-2018). Within it, we developed the Model M method (MMm) as a new requisitely holistic approach to youth training, in terms of their personal and social responsibility, to reduce their unemployment. We also present the results of the project, the social return on investment (SROI) calculation and potential further research on the topic.

\section{Theoretical Backgrounds}

McKinsey \& Company (Mourshed et al., 2014) surveyed 5300 young people, 2600 employers and 700 postsecondary education providers across 8 countries which represent home to almost 73 percent of Europe's 5.6 million jobless youth: France, Germany, Greece, Italy, Portugal, Spain, Sweden and the United Kingdom. They also examined more than 100 programs in 25 countries to provide examples of companies, governments, education providers and nongovernmental organizations that may be relevant to 
Europe. Their research led them to the following answers (summarized conclusions):

1. While there are more people looking for work, employers in Europe cannot find the skills they need. (So why is it that young people are not getting the skills that employers need? One reason is the failure of employers, education providers and young people to understand one another. To cite the McKinsey \& Company 2012 report, they operate in "parallel universes.”).

2. Young people face three significant hurdles on which they should be focused. (The education-to-employment (E2E) path can be described as a road with three intersections: enrolling in postsecondary education, building the right skills and finding a suitable job. The problem is that, in Europe, there are roadblocks at each of these three points.)

3. The E2E structure is failing for young people and for small businesses. (Only one of their segments, the so-called high achievers, which represent 10 percent of the youth surveyed, achieves a good employment outcome. This group succeeded because the young people in it receive a strong education and good information; they also focus on finding opportunities to build job skills. Another two segments, representing 11 percent of youth surveyed - what they call "coasters" and "meanderers" - receive strong support but are less motivated and end up only moderately satisfied with their job outcomes. The remaining four segments (79 percent) are frustrated by a lack of support and unhappy at their prospects. They exhibit different responses to these circumstances, from fighting for every opportunity they can get (but rarely succeeding) to losing heart and leaving education at the first opportunity.)

4. There are proven ways to improve the E2E journey. (Europe's governments, employers, education providers and families are operating in difficult circumstances, but there are ways to ease the burden on all of these groups; for example, innovate with design, course delivery and financing to make education more affordable and accessible; focus young people, employers and education providers on improving employment readiness; build the supporting structures that allow the best interventions to scale up; or involve the European Union.)

The role of education (Buchert, 2014) in fostering economic growth and sustainable development has, therefore, been reinforced with particular attention to its link to the labour market, in part to create knowledge and a highly skilled workforce to ensure economic competitiveness in a global economy characterised by flexibilisation and deregulation. At the same time, its role in facilitating social cohesion and social justice remains pertinent, affecting the relationship between diversity, inclusion and citizenship.
Young people need to be equipped with the skills required to access the world of work, including skills for self-employment (Feldt et al., 2018). Thereby, skills refer to the ability to apply knowledge, use know-how to complete tasks and solve problems and carry out the tasks that comprise a particular job. If they lead to decent employment, they can be enabling and empowering factors. Beside technical skills, life skills are important for the general wellbeing of individuals and lead to better employability. A key challenge in many developing countries is addressing the skills needed for accessing decent employment both in terms of formal employment and self-employment. In this regard, training and formal Technical and Vocational Education and Training (TVET) systems play an important role in equipping youth with the skills required for bridging the skills gaps and empowering young people with education and training that is key for the realisation of their full potential. In the 2030 Agenda for Sustainable Development (UN, 2015), the signatory states also agreed on the need for youth skills development with clear indicators under Goal 4, Target 4.4, which commits to "By 2030, substantially increase the number of youth and adults who have relevant skills, including technical and vocational skills, for employment, decent jobs and entrepreneurship.” It is therefore essential to ensure that education is holistic, not only addressing quickly changing technical skills, but also focusing on greater life skills.

There are two situations (UK Government Office for Science, 2017) where the demand for and supply of skills are out of kilter: skills surpluses, where the supply of skills exceeds demand, and skills deficits, where the demand exceeds supply. 'High skills equilibria' or 'low skills equilibria' are circumstances where the skills required by employers are matched by the skills provided by employees, but the latter can cause significant economic and social problems.

The OECD Learning Framework 2030 (OECD, 2018) therefore encapsulates a complex concept: the mobilisation of knowledge, skills, attitudes and values through a process of reflection, anticipation and action, in order to develop the inter-related competencies needed to engage with the world. To ensure that the new learning framework is actionable, the OECD Education 2030 stakeholders worked together to translate the transformative competencies and other key concepts into a set of specific constructs (e.g. creativity, critical thinking, responsibility, resilience, collaboration) so that teachers and school leaders can better incorporate them into curricula.

Building on the OECD (2018) Key Competencies (the DeSeCo project: Definition and Selection of Competencies), the OECD Education 2030 project identified three 
further categories of competencies, the "Transformative Competencies", that together address the growing need for young people to be innovative, responsible and aware (OECD, 2018):

- $\quad$ Creating new value;

- Reconciling tensions and dilemmas;

- $\quad$ Taking responsibility.

Corporate Social Responsibility contributes to the sustainable development of organizations that choose to integrate the environmental and social issues faced by modern human society (Stanescu \& Comandaru, 2019). In other words, everyone benefits from the use of social responsibility programs: the organization that paves its way to business success by increasing profits and creating long-lasting relationships with the stakeholders, and disadvantaged communities that receive support for local development. This effort may include the MMm as a part of the stakeholders' relations, but we detected no references yet to the MMm in Web of Science, Science Direct, Wiley Online Library, Scopus, or Google Schoolar (visited in December 2019). The MMm is the result of practical experiences of IRDO members, including all ages and many professions.

The benefits of skills development and lifelong learning (UK Government Office for Science, 2017) are multifaceted and accrue in many ways across the economy and society. A number of the benefits are interlinked: for example, any impact on employment outcomes can have benefits for the individual as well as the state and society. Generally, returns from spending on learning can be considered with respect to:

- Benefits to the individual, for example increases in wages and the probability of remaining in employment;

- Benefits to the employer, for example greater profitability (also positively affecting society);

- Benefits to society, including public health benefits, reduced welfare dependency and higher tax revenues.

Target 8.b in the 2030 Agenda for Sustainable Development reads (ILO, 2019): “By 2020, develop and operationalize a global strategy for youth employment and implement the Global Jobs Pact of the International Labour Organization." The associated indicator involves looking for the "[e]xistence of a developed and operationalized national strategy for youth employment, as a distinct strategy or as part of a national employment strategy."

Target 8.6 (ILO, 2019) calls for countries to "substantially reduce the proportion of youth not in employment, education or training [(NEET)].” Importantly, this target must be achieved by 2020, reflecting the urgency of generating adequate employment opportunities for the next generation of workers. When young people find themselves in a NEET situation, it means they are not gaining skills that are valued in the labour market, which reduces their future chances of finding employment. In the long run, this both condemns young people to social exclusion and undermines the ability of an economy to grow over a sustained period (ILO, 2017; ILO, 2019).

\section{Methodology}

For our research, we used a case study, i.e. the Model M Slovenia project. A logical plan was made based on five important components:

- The research question (2),

- The study's propositions (the Model M project will continue its work in the following years),

- The study's units of analysis (the Model M project),

- The techniques for the logic linking of the data to the proposition (the SROI method of social impact measurement),

- The criteria for interpreting the case study's findings (number of employments, investment in EUR into the project and social return on investment).

The research questions were: (1) What kind of holistic approach could help young people become (self-)employed as soon as possible? and (2) What could be the new method for reducing youth unemployment?

For this case study, we used direct observation as the method for collecting data. The research participants were those participating in the Model M project (unemployed youth, experts, volunteers, managers of enterprises etc.).

In the process of collecting data and case study evidence, we used study notes, documents, tables and narratives from the Model M project implementation, which are also kept as the chain of evidence for the reports required by the Ministry of Education, Science and Sport of the Republic of Slovenia (co-funder of the Model M Slovenia project).

We analyzed the evidence of the data collected in the empirical study using quantitative (numbers) and qualitative data (words, descriptions). Because case studies are mostly based on qualitative data, we focused on this part, but as in our case we also added the SROI calculation, we used mixed methods.

Our research had several limitations: firstly, we focused only on one organization and one project, and not more, in this field of research; secondly, we used only one method of social impact measurement (SROI) instead of combining several of them; and thirdly, we applied a limited period of time and limited resources to the research. 


\section{The Model M Slovenia Project Case Study}

\section{The emergence and development of the Model M small projects}

The Model M Slovenia project is an upgrade of the pilot implementation of the Model M small projects - a training program for youth, tested and improved in the Podravje region in years 2012-2016 (Podravje: 2012-2013 Model M; 2014 Model M; 2015 Model M Express; 2016 Model M (r) evolution). The Model M Slovenia project was the expansion of this training program for young people in six other regions of Slovenia and contributed to IRDO's expanding its network and activities in seven Slovenian regions (Pomurje region, Savinjska region, South-east Slovenia, Central Slovenia, Upper Carniola, Goriška region, Coastal-Karst region).

The project presented a bridge between theory and practice in training and employment of young people, and also enriched the work of the IRDO Institute. It upgraded the pilot implementation of this kind of training, which was tested in the Podravje region earlier, and enabled its dissemination and upgrading around Slovenia. IRDO's visibility, including all involved in the project, was raised, too. It provided two jobs at the IRDO Institute and part-time jobs for more than 80 experts (training, counseling, authorial and other professional work) as well as more than 50 other new employments for young people.

\section{Model $M$ means being young and a model of success}

The Model M means being young and being a role model for others in finding innovative employment or creating one's own employment, and thus becoming and remaining an active citizen. The purpose of the Model M Slovenia project was to empower young people with training, networking, counseling and active participation in the society to create their own success models.

In order to secure their first jobs (Brewer, 2013) as well as navigate in the labour market, young women and men need the technical skills to perform specific tasks as well as core work skills: learning to learn, communication, problem-solving and teamwork. Development of core skills, awareness of workers' rights and an understanding of entrepreneurship are the building blocks for lifelong learning and capability to adapt to change.

The ILO defines employability skills as (Brewer, 2013): “... the skills, knowledge and competencies that enhance a worker's ability to secure and retain a job, progress at work and cope with change, secure another job if he/she so wishes or has been laid off and enter more easily into the labour market at different periods of the life cycle. Individuals are most employable when they have broad-based education and training, basic and portable high-level skills, including teamwork, problem solving, information and communications technology (ICT) and communication and language skills. This combination of skills enables them to adapt to changes in the world of work."

Employability (Brewer, 2013) results from several factors a foundation of core skills, access to education, availability of training opportunities, motivation, ability and support to take advantage of opportunities for continuous learning, and recognition of acquired skills - and is critical for enabling workers to attain decent work and manage change and for enabling enterprises to adopt new technologies and enter new markets.

Life skills training (IYF, 2014) is most effective when it offers young people a foundational basis to be healthy and productive members of their communities. The challenge in designing the program which aims to increase youth employability will be to identify or create a curriculum that:

- Encompasses key or “core” life skills;

- Emphasizes workplace-readiness skills and behaviours;

- Is demand-driven by incorporating the skills employers regard as paramount for hiring and job-success;

- Is flexible enough to incorporate additional life skills identified through consultation with other key stakeholders (training institutes, government ministries, educators, etc.).

- That is why the Model M Slovenia project had several objectives in the years 2016-2018:

- To increase the employability and employment of young people aged 15 to 29 in the labour market in at least seven statistical regions of Slovenia (in enterprises and non-governmental organizations and elsewhere);

- To increase the diversity of approaches to the employment of young people (innovative job search, creating their own employment through their own organization) with the help of entrepreneurial networks, regional chambers of commerce and career centres at universities, and through youth work and cooperation with non-governmental organizations;

- To strengthen the competences of young people for active citizenship and to encourage the social recognition of these competences through a training program, awarding young people for their best career and business plans, and linking them with entrepreneurs and non-governmental organizations and promoting these links;

- To train regional organizations in the youth sector to address and solve the problem of youth unemployment, and thus, in a sustainable way, strengthen the 
competences of youth workers, youth work and its socio-economic potential, also through the "Train the Trainer” program.

Through the entire training program, young people, receiving practical advice from various professionals and entrepreneurs, and evaluating their own cultural (knowledge, education, skills), social (social environment, social class, social status) and psychosocial potentials (personality traits and orientations), generated their career plans or business plans and implemented them with the support of IRDO and its partners.

\section{Creation of the Model M Slovenia Community}

The purpose of the Model M Slovenia Community is to exchange the information on employment, training, business opportunities and good practices. The emphasis is on the networking between young people and businesses and other organizations. Within the Model M Slovenia, IRDO organized speed business meetings between young people and entrepreneurs in each region.

The fact that benefits are spread across the society raises a question about the appropriate form and level of learning provided by the constituent parts of society, in particular the individual, employer and the state (UK Government Office for Science, 2017). The types of skills are in demand by employers and the shortcomings of labour market entrants. Possessing a good work ethic and character skills, such as responsibility, integrity and self-management, are perceived by many employers as highly important, yet many applicants appear to lack these attributes. Possible approaches to helping individuals develop these skills before they enter the working world are discussed, as are the roles of the employer and education provider in achieving this goal.

The IRDO Institute brought together different groups of people in the community:

- Candidates for employment (young people actively seeking employment);

- Providers of products and services (young people who have set up their own enterprise or non-governmental organization);

- Jobseekers (organizations and other legal entities that are looking for suitable candidates for employment);

- Providers of internships and practices (enterprises and other legal entities that can offer internships or practices to young people);

- Lecturers and counselors for young people (entrepreneurs, non-governmental and other professionals who are ready to advice young people);
- Youth organizations and other organizations that are trained to strengthen the employability and employment of young people in the region;

- Young people who have already found a job or created their own.

The Model M Community, within the Model M Slovenia project, acquired 118 new young participants in 2016-2018, more than 80 new lecturers, 14 regional partners and many others. Its social capital is even greater, if we add more than 150 Model M members from the Podravje region from previous years and more than 140 existing IRDO members who have been able to support the development of this project with their networking. More about activities, results and evaluation of Model M Slovenia can be found on the website at www.model-m.si.

\section{The development of the Model M method}

According to the Model M method (MMm), a new participant is first invited to an informative meeting where the training program is presented, along with the MMm way of cooperating through "models" - former participants who have already completed the Model M training. New applications for the training are also accepted at the informative meeting.

The first day of the training is usually also the first day of the first out of 6 weeks of training, which consists of 2 or 3 days per week, 15 days in total. Excellent lecturers and consultants provide more than 100 hours of discovery, sharing experiences, storytelling and learning to know more about entrepreneurship and consulting in almost every region.

\section{The content of the Model M Slovenia training}

Life skills training (IYF, 2014) is most effective when it offers young people a foundational basis to be healthy and productive members of their communities. The challenge in designing the program which aims to increase youth employability will be to identify or create a curriculum that:

- Encompasses key or “core” life skills;

- Emphasizes workplace-readiness skills and behaviours;

- Is demand-driven by incorporating the skills employers regard as paramount for hiring and job-success;

- Is flexible enough to incorporate additional life skills identified through consultation with other key stakeholders (training institutes, government ministries, educators, etc.).

The MMm training consists of 6 modules, carried out over 15 days, and offers the following content: 
1. “Me and My Plans”: discovering one's mission, skills and limitations - homework, group lectures and discussions;

2. Career planning and business environment - group lectures and discussions, visits toorganizations with good practices, homework;

3. Consultancy (group and individual), homework;

4. Learning about the business and employment environment - group lectures and discussions, visits to organizations with good practices, homework;

5. Finding opportunities for work and visiting organizations with good practices, networking;

6. Presentation of the candidate's career or business plan and consultation with other participants.

The content of the training program (Hrast \& Rajšp, 2018) includes:

- Getting to know oneself and others, personal growth and easier transition to the labour market; decision for a sole-entrepreneurial or non-governmental path, active employment;

- Acquiring knowledge and skills for the following classes (work in 3 groups):

A. Establishment and operation of one's own business;

B. Establishment and operation of a non-profit organization;

C. Active job search in the labour market;

- Writing one's own career or business plan and other exercises.

\section{Methods of work, duration, performers}

Methods of work include group lectures, individual workshops, meetings, consultations, visits to organizations with good practices, storytelling, networking, sharing experiences.

The process of training revealed that day-to-day task performance and job-orientation are key. The tasks are designed in a way that allows the participants to first learn about themselves and each other through public presentations. This creates an atmosphere of understanding, acceptance and integration.

During their public speaking within the group, the participants share their views on the attendance of the trainer and suggest improvements, present themselves in front of the group and provide feedback to each other. The first three days of training are crucial for making the group a community. The moderator plays an important role: connects the group through his/her work, gives feedback, encourages and offers improvements, and ensures the respect of the training participants.
The group is subject to agreed upon rules, namely:

1. Everything that happens in the group remains in the group;

2. Confidential personal information and information about a person must not be shared with others;

3. The rule of constructive criticism - if your criticism cannot awaken something positive in a person in a positive way, be quiet;

4. Everyone in the group is respected and the participants try to awaken the best in everyone, so that they can show it to others;

5. Members connect each other, regardless of gender, race, orientation, culture, religion, etc. and help each and every one find a job as soon as possible - with recommendations, exchange of information, linking, encouraging each other to personal development - all in a positive way by creating a positive climate in the group.

Every day, the participants appear in front of the group - they present their tasks, and thus themselves, and strengthen their public speaking skills or overcome stage fright. External lecturers provide several lectures; they always speak about themselves - how they first started, what kind of entrepreneurial and employment experiences they have gained, what they have learned so far in their years of experience and what they would recommend to the participants in the training. It is a valuable experience that gives young people the courage to make something out of themselves.

\section{Measuring the social impact of the Model M Slovenia project}

The IRDO Institute (Hrast, Kojc \& Mulej, 2014), in cooperation with the Ministry of Labour, Family, Social Affairs and Equal Opportunities in Slovenia, Europe, prepared a Study on Measuring the Social Effects of Social Enterprises. Within this study, a model for measuring the impact on the society was developed, and now social enterprises (and other organizations) can evaluate the results of their work and effectively present them to the general public and other interested parties (co-financiers, investors, managers). On June 6, 2014, IRDO organized a working meeting in Ljubljana with a workshop on the measurement of social effects of social enterprises, attended by 15 representatives of Slovenian social enterprises. With them, the instructions, the model of calculation and the questionnaire were upgraded by including their updates.

At the meeting, IRDO also presented important aspects of the measurement of social effects and the positive impact of such measurement for the successful operation of social enterprises. IRDO presented two practical examples of using the emerging model of measuring the social effects of Slovenian 
social enterprises, one of which was the Model M project, implemented by IRDO in the Podravje region. Within the workshop, social enterprises could fulfill the questionnare and the Social Return on Investment (SROI) calculation and thus measure their social effects (subsequently).

With the help of the workshop, the participants got an insight into the complexity of this kind of measurement. It helped them to think structurally about the goals that the social enterprise poses, the way of doing business, the potential market, the acquisition of financial resources, and the clearer formation and communication of one's own identity, the financial evaluation of their own activities and the achievements that help them earn income. Together with the participants in the workshop and within the discussions, IRDO co-created the adjustments of the Slovenian model of measuring social impact (IRDO, 2018), making it more usable and practical for Slovenia.

The goal of impact measurement is to manage and control the process of creating social impact in order to maximise or optimise it (in relation to costs). Managing impact occurs continuously and is facilitated by integrating impact measurement in the investment management process. It is important to identify what you may need to change within the investment management process so that you are able to maximise social impact. That is why managing impact is the core of the impact measurement process. For each step in the process, one should consider how this relates to the everyday work of funding and building a stronger social purpose for organisations.

Social return on investment (SROI) is a method for measuring values (Folger, 2019) that are not traditionally reflected in financial statements, including social, economic and environmental factors. It can identify how effectively an enterprise uses its capital and other resources to create value for the community. While a traditional cost-benefit analysis is used to compare different investments or projects, SROI is used more to evaluate the general progress of certain developments, showing both the financial and social impact the enterprise can have. SROI is useful to enterprises because it can improve program management through better planning and evaluation. It can also increase the enterprise's understanding of its effect on the community and allow better communication regarding the value of the enterprise's work (both internally and to external stakeholders). Philanthropists, venture capitalists, foundations and other non-profits may use SROI to monetize their social impact in financial terms. A general formula used to calculate SROI is as follows: $\mathrm{SROI}=(\mathrm{SIV}-\mathrm{IIA}) /(\mathrm{IIA} \times 100 \%)$, where: $\mathrm{SIV}=$ social impact value, IIA=initial investment amount. Assigning a dollar value to the social impact can present problems, and various methodologies have been developed to help quantify the results. The Analytical Hierarchy Process (AHP), for example, is one method that converts and organizes qualitative information into quantitative values. While the approach varies depending on the program that is being evaluated, there are four main elements that are needed to measure SROI:

- Inputs, or resources investments in your activity (such as the costs of running, say, a job-readiness program);

- Outputs, or the direct and tangible products from the activity (for example, the number of people trained by the program);

- Outcomes, or the changes to people resulting from the activity (i.e., new jobs, better incomes, improved quality of life for the individuals; increased taxes for, and reduced support from the government);

- Impact, or the outcome minus an estimate of what would have happened anyway (for example, if 20 people got new jobs but five of them would have been hired in any event, the impact is based on the 15 people who got jobs directly as a result of the job-readiness program).

Model M-a training program that teaches young unemployed persons about entrepreneurship and non-government organizations, and offers counseling and visits to good practiceswas piloted in the period 2013-2016 in the Podravje region. At the end of 2014, we prepared a calculation, with help of the SROI method, for measuring the effects of this project on the wider society.

In further description of the Model M Slovenia project case study, we present the results of measuring the social impact of the Model M Slovenia project, as prepared for the purposes of the study in 2014 (Hrast, Kojc \& Mulej, 2014) as an example with adaptations to be used in Slovenia. For the calculation, we used the SROI spreadsheet and additional attachments to assist in the selection of the indicators.

At the beginning of measuring the social impact of the Model M Slovenia project, we planned our social impact according to framework Dimensions of Social Performance (Leclair et al., 2013). We defined the mission of the project, its objectives, internal system of work and activities required to achieve our social impact. We also defined the planned outputs and outcomes. At the end, we tried to define our social impact by answering the question: What change can be made for the participants and in the society with our action?

Later, we began to calculate the social impact for the Model $\mathrm{M}$ project using a model for calculation with key definitions in impact measurement (Hehenberger et al., 2013) and the social return on investment (SROI) method (Hrast, Kojc \& Mulej, 2014; Folger, 2019). The process of impact measurement has two dimensions: organization's planned 
work (inputs and activities) and organization's intended results (outputs, outcomes and impact). Inputs were our resources (volunteer work, EU Funds, etc.) invested in the activity. Activities were concrete actions of the organization (education, training, etc.). Outputs were tangible products from the activity (number of employed youth). Outcomes were changes, benefits, learnings, effects resulting from the activity (increased level of trainned youth). Impact was attribution of our organization's activities to broader and longerterm outcomes (cooperation with other organizations, creation of a supportive environment for (self-)employment of young people).

In the further report of the SROI calculation, we tried to present how the investment of 103,180.00 EUR (input) can make a change through activities (of the Model M project) for an organization and for the society (total net present value of 983,741.27 EUR). This means that the planned reimbursement value per invested amount of 1 EUR was 10.53 EUR. The report also explains which stakeholders were included, what inputs, activities and results were gained outputs, outcomes and impact.

Table 1 presents the financial results of the calculation, where the investment of every euro should be reimbursed in the social contribution of 10.52 EUR within 4 years of the project impact.

The result (see Table 1): the investment of every euro was reimbursed in the social contribution of 10.53 EUR within 4 years. The opinion on the achieved result of the SROI: We believe that the calculated SROI is a good basis for reflection on the social reimbursement of such activities. It is based on a subjective assessment, but verified by several official sources of information. It could reflect the picture of possible reimbursements of such activities of the IRDO Institute to the society (Hrast, Kojc \& Mulej, 2014) in the future, as described in Table 2 and in the section Results (where we explain that the contribution in the following years (after 2014) really was ten-fold).

Investing in youth training, as with the Model $\mathrm{M}$ project in the Podravje region, has a large impact on the society (as explained in Table 2). This is also demonstrated by the building of the Model M Community, as described in the section Results.

\section{Research results: Evaluation of the Model M Slovenia project}

The example of the Municipality of Maribor confirms that the support offered for the Model M project pilot is in fact later also financially remunerated, in this case more then ten-fold. Namely, the Municipality of Maribor co-financed the project in the period from 2012 to 2017 in the amount of EUR 39,856.86. The IRDO Institute made a broader impact, thanks to this source, in the following years (2016-2018) with the amount of EUR 339,206.59 gained through a public tender of the Office of the Republic of Slovenia for Youth and European Social Fund for the Model M Slovenia project (to support the employment of more than 50 young people in Slovenia, see more details at www.model-m.si).

At the end of the Model M Slovenia project, the IRDO Institute research group (Hrast, Rauter \& Rajšp, 2018) also evaluated the entire project with one qualitative and two quantitative researches among 118 project participants, their trainers and lecturers in seven Slovenian regions. Based on the descriptive responses of 16 opinion leaders, entrepreneurs, advisers, non-governmental speakers, lecturers and young participants from the Model M Slovenia project, it was found that similar people were involved in the project, with a high degree of proactivity and awareness of themselves and their surroundings.

Table 1. SROI calculation result - financial summary for the Model M project (2014)

\begin{tabular}{|c|c|c|c|c|}
\hline SUMMARY of calculation for 4 years of impact in EUR & $\begin{array}{c}\text { YEAR 0 } \\
\text { (starting year 2013) }\end{array}$ & $\begin{array}{l}\text { YEAR 1 } \\
(2014)\end{array}$ & $\begin{array}{l}\text { YEAR 2 } \\
(2015)\end{array}$ & $\begin{array}{l}\text { YEAR } 3 \\
(2016)\end{array}$ \\
\hline Total per year in EUR & $299,220.00$ & $331,868.00$ & $279,281.60$ & $228,776.72$ \\
\hline Present value each year & $299,220.00$ & $320,645.41$ & $260,712.36$ & $206,343.49$ \\
\hline Total present value (PV) in 4 years & & & & $1,086,921.27$ \\
\hline Input & & & & $103,180.00$ \\
\hline Net present value (NPV = PV minus input) & & & & $983,741.27$ \\
\hline Social return on investment (SROI) & & & & 10.53 \\
\hline Reimbursement value per invested amount of 1 EUR $=$ & & & & 10.53 EUR \\
\hline
\end{tabular}

Source: Hrast, Kojc \& Mulej, 2014 
Table 2. Impact report for the Model M project in the Podravje region (2012-2014) - calculation in 2014

\begin{tabular}{l} 
Report components Description \\
\hline Summary
\end{tabular}

The reporting date and the covered period of activity and impact

27 May 2014, 1 year of implementation, 3 years of influence measurement

\begin{tabular}{ll}
\hline Overview of the report & Ministry of Education, Science and Sport, Republic of Slovenia \\
\hline Mission & \\
\hline Mission description & $\begin{array}{l}\text { The mission of the project is to train } 30 \text { young people for employment within two months } \\
\text { or to establish their own legal entity (profit, non-profit). }\end{array}$
\end{tabular}

How do you understand the problem that you are trying to deal with?

Currently a very topical problem in society.

How do you respond to it with your key purposes, approach and the fundamental orientation of your work?

How do you respond to your users?
We developed the Model M project - a program for training young unemployed people for entrepreneurship and non-governmental jobs, supporting them with consulting and viewing examples of good practices.

\section{Activities and results}

What were your activities during the reporting period? Can you create a spreadsheet?

We listen to their needs and adapt the program to them.

Within the framework of the project, the partners carried out the following activities in 2012-2014:

1. Project management and coordination (management, organization, reporting and other activities)

2. Model M 2014 - Summer-Autumn School (training program for young unemployed persons and students for entrepreneurship, non-governmental and innovative job search).

3. Motivating the participants in the training program for the best entrepreneurial, nongovernmental and career plans.

4. Research among the participants in the 2013-2014 training program on satisfaction with the program and proposals for the development of the city in terms of the development of youth entrepreneurship and non-government.

5. Networking and promotional activities for the project, evaluation, dissemination of the program and inclusion of a wider population of young people and entrepreneurs in the development of urban entrepreneurship and non-governmental work (intergenerational collaboration, international cooperation).

Objectives of the project (impact chain) are:

- Young people: They should be more trained in finding a job; they should get the knowledge and advice to establish their own legal entity, they should get employment faster in the labour market, their social capital should increase and other impacts;

- Professional staff of support institutions: Gaining insight into the needs of job-seekers, strengthened support networks for jobseekers, knowledge sharing between the professionals from supporting institutions;

- Volunteers: Acquiring knowledge to work with the unemployed, strengthening the social network, acquiring skills in the framework of the unemployed program, the volunteer prize;

How are activities transmitted to your influence?

Can you show your impact chain?
- Employers: Staff recruitment for potential employment, promotion of the employer, strengthening the social network, establishing the cooperation with the local community, obtaining proposals for improving the business;

- Volunteers-lecturers (entrepreneurs, experts): Promotion of the lecturer, strengthening the social network, establishing the cooperation with the local community, obtaining proposals for improving the lectures, a set of potential new employees, sales of products/services;

- Co-financers (local community, sponsors and donors): Reduction of the number of unemployed persons, greater involvement of actors in the local community, promotion of the co-financer, identification of the needs of other target groups and proposals for new forms of co-financing;

- Investors (e.g. start-up organizations): They can invest in new legal entities, promotion of the investor, strengthening of social capital, profit. 
Table 2. Impact report for the Model M project in the Podravje region (2012-2014) - calculation in 2014 (cont.)

\begin{tabular}{|c|c|}
\hline Report components & Description \\
\hline $\begin{array}{l}\text { What were the results of the } \\
\text { reporting period? } \\
\text { - Indicators used } \\
\text { - Recorded values (outcomes and } \\
\text { indirect outcomes) } \\
\text { - Inputs used (costs, resources) }\end{array}$ & $\begin{array}{l}\text { Indicators used: } \\
\text { - No. of completed trainings of participants; no. of new jobs on the market; no. of new } \\
\text { established legal entities (plan: at least } 20 \text { trained unemployed persons, at least } 2 \text { legal } \\
\text { entities newly registered, at least } 2 \text { new employment of unemployed persons); } \\
\text { - No. of conducted lectures, no. of hours, no. of lecturers involved; } \\
\text { - No. of hours worked by volunteer work, no. of volunteers, no. of days of cooperation; } \\
\text { - No. of hours spent for business visits, no. of participants of the tour, no. of days of } \\
\text { cooperation, no. of potential candidates for employment; } \\
\text { - No. of hours spent on lecturing, no. of experts, no. of days of cooperation, no. of new } \\
\text { persons employed due the training program; } \\
\text { - No. of social innovations, no. of employed persons, no. of publications in the media, } \\
\text { proposals for new programs, tenders; } \\
\text { - No. of new founders, no. of new legal entities, no. of announcements in the media about } \\
\text { the investor. } \\
\text { Recorded results: } \\
\text { - Training for } 30 \text { people in the amount of } 127 \text { hours per } 10 \text { eur/hour a group (for } 30 \\
\text { people); individual counseling for them by appointment; } \\
\text { - } 10 \text { people, } 60 \text { hours of counseling work, } 15 \text { eur/hour; } \\
\text { - } 5 \text { volunteers, } 30 \text { working days per } 8 \text { hours, } 10 \text { eur/hour for volunteer work; } \\
\text { - } 3 \text { views of organizations with good practice examples, } 3 \text { working days per } 8 \text { hours, } 15 \\
\text { eur/hour for managing a good practice in the enterprise; } \\
\text { - } 10 \text { professional volunteers, } 10 \text { working days per } 8 \text { hours, } 15 \text { eur/hour (value for } \\
\text { payments of professional work); } \\
\text { - Co-financing the project in the amount of } 30 \% \text { of the total project's assets; } \\
\text { - Launch of } 2 \text { profit organizations and } 2 \text { NGOs, promotion of the investor in } 2 \text { media, } \\
\text { collection of profits in the } 3 \text { rd year of operation of these start-ups; } \\
\text { In the total amount of } 1,086,921.27 \text { EUR. } \\
\text { Inputs used: } \\
\text { - Time, work, money for a total amount of } 103,180.00 \text { EUR. }\end{array}$ \\
\hline
\end{tabular}

SROI calculation

The investment of every euro will be reimbursed with the social contribution of 10.53 EUR in 4 years.

Your broader impacts

The wider impacts are cooperation with other organizations in the Podravje region and joint creation of a supportive environment for (self-)employment of youth.

Non-intended or negative indirect Negative indirect outcomes have not been recorded in the project. outcomes

Checking and responding

Comparing the results with your plans and goals for a given period; key factors

Lessons learned and therefore the foreseen changes? Explain them!

Your view of how the external situation develops (risks, opportunities)? Explain...

Your plan for the next year (2015)

is ...?

How do you plan to measure the success of the plan (purpose, objectives)?

Your more long-term strategy for the future is...?
Since this was a forecast, we estimated that we can carry out the project in the first year (if funds were available), and with the same support, we can help the next generation of young people.

We will need more cooperation with entrepreneurs and the creation of additional education for youth if we want to make Slovenia more entrepreneurial. This also applies to social entrepreneurship, where entrepreneurial skills and non-government knowledge are lacking.

We need more support from the government in education development and its implementation for youth and social entrepreneurship, and other related topics.

Enroll the next generation of young people and connect all previous generations in terms of mutual support and joint development. Educate for social entrepreneurship.

Indicators as mentioned above and monitoring SROI calculations for individual years, this time in the form of retrospective reports.

Encourage the development of social responsibility in all Slovenian organizations and all residents of Slovenia. This also includes the promotion of entrepreneurship, social entrepreneurship, and so forth.

Source: Impact Report for the Model M project, year 2014 - Annex to the SROI calculation for the Model M Podravje project (Hrast, Kojc \& Mulej 2014) 
Their answers imply that all of them give importance to lifelong education and complement formal education with non-formal education. Model M Slovenia was designated as an important added value for young people on their way to employment due to many already tested positive effects (Hrast, Rauter \& Rajšp, 2018). The young participants complimented and thanked the Model M Slovenia project (as well as the Ministry of Education, Science and Sport of the Republic of Slovenia, the Office of the Republic of Slovenia for Youth and the EU's Social Fund) for offering them a good opportunity to get to know themselves and their competences better, and through this, more clearly define their employment and life path.

The online survey, performed after the conclusion of the Model M Slovenia project in 2018, included lecturers, moderators and other project-related persons, and was answered by 27 people. As many as $77 \%$ of them are extremely satisfied with Model M Slovenia, giving it the highest rating. 73\% found a great need for the Model M Slovenia training to continue. The respondents also assessed only one day of the Model M Slovenia project training, i.e. the day they were present. Other results include: $88 \%$ of the highest score for the training concept, $84 \%$ of the highest score for the communication with young people, $77 \%$ of the highest score for the completion of one study day as a whole.

The findings from the research and evaluation of the project show that the participants, lecturers and others involved in the project are mostly satisfied with the project and that the effects of the project are very visible. By the end of May 2018, 50 participants out of 118 were employed (42.37\%), while at the end of the project (15 September, 2018), the participants expected at least a few more jobs.

In order for the Model M Slovenia project to most easily continue, funds are the most crucial, according to most respondents. Both those involved and those not involved in the project consider that young people themselves will not be able to finance such projects in the future, and that, if the European Union provides the funds, the state and/or the local community is the best co-funder. Only a small proportion of them are willing to pay for this type of training.

\section{Discussion}

Students (OECD, 2018) will need to apply their knowledge in the unknown and in the evolving circumstances. For this, they will need a broad range of skills, including cognitive and meta-cognitive skills (e.g. critical thinking, creative thinking, learning to learn and self-regulation); social and emotional skills (e.g. empathy, self-efficacy and collaboration); and practical and physical skills (e.g. using new information and communication technology devices). The use of this broader range of knowledge and skills will be mediated by attitudes and values (e.g. motivation, trust, respect for diversity and virtue). The attitudes and values can be observed at personal, local, societal and global levels. While human life is enriched by the diversity of values and attitudes arising from different cultural perspectives and personality traits, there are some human values (e.g. respect for life and human dignity, and respect for the environment, to name but two) that cannot be compromised.

What do young people want after the Model M Slovenia project? The respondents want more content in the field of career orientation in regular education - secondary and higher education or at least a continuation of the co-financing or financing of projects such as Model M Slovenia, and at least a partial mentoring for young people. Most funds are expected from the state and the European Union. The classical content is still current, e.g. young people are happy to hear how to present themselves to the employer, how to write a CV, how to publicly perform, enter into entrepreneurship and use social networks. The content that is very or even most sought after is learning about oneself and one's abilities, setting one's own goals and knowing one's own competences.

According to young people, the strongest channels for promoting Model M Slovenia are social networks, followed by links and presentations among young people in schools and faculties, while the older ones think the opposite, and experience has shown that it is necessary to be very skillful and innovative in acquiring participants. The combination of both definitely supports the young, and above all, the quality of the program, the quality of the speakers, a good choice of location and a meaningful time scale.

The question arises as to whether it would be reasonable to use Model M Slovenia, as a project or state measure, and include it into the existing curricula of all educational institutions in Slovenia (for example, for the last years of vocational and secondary schools and faculties). This would not only cover the entire population but, with the Model M Slovenia training method, also connect as many young people as possible with the economy, profit and non-profit organizations, non-governmental organizations and educational institutions.

One of the most important roles in an enterprise is to ensure that employees have the right skills and competences to achieve successful business results. Based on the results, 
we found (Rožman et al., 2019) that appropriate approaches of knowledge management have a significant positive impact on work engagement of employee knowledge in Slovenian enterprises.

Education (OECD, 2018) has a vital role to play in developing the knowledge, skills, attitudes and values that enable people to contribute to and benefit from an inclusive and sustainable future. Learning to form clear and purposeful goals, work with others with different perspectives, find untapped opportunities and identify multiple solutions to big problems will be essential in the coming years. Education needs to aim to do more than prepare young people for the world of work; it needs to equip students with the skills they need to become active, responsible and engaged citizens.

As an institution (Buchert, 2014), education has a critical role to play for the life chances of youth and their inclusion in or exclusion from social opportunities. The issue of learning outcomes is therefore central to policy discussions nationally and internationally.

\section{Conclusions}

Our research questions were:

(1) What kind of holistic approach could help young people become (self-)employed as soon as possible?

(2) What could be the new method for reducing youth unemployment?

We can conclude that the answer to the first question is social responsibility. This conclusion links the Model M Slovenia viewpoint with the concept of social responsibility - society is composed of individuals, their relations and synergies. Young individuals tend to graduate from narrowly specialized education programs, usually without enough knowledge, know-how and values, and they tend to need to activelly join an interdisciplinary creative cooperation with other individuals from a similarly narrow education. Neither of them acquire enough entrepreneurial knowledge, know-how or values. The third missing part in current education programs is social responsibility as a human, organizational and societal attribute (see more in: Mulej et al., 2019; Mulej et al., 2016 a, b, c, d; Mulej, Dyck et al., 2014 a, b; Mulej et al., 2013 a,b; Lebe, Mulej et al., 2014; Mulej et al., 2015; etc.).

Social responsibility in ISO26000:2010 (ISO, 2010) has the organization as its focus and concerns the responsibilities of an organization to society and the environment. Social responsibility is closely linked to sustainable development.
Because sustainable development is about the economic, social and environmental goals common to all people, it can be used as a way of summing up the broader expectations of society that need to be taken into account by organizations seeking to act responsibly. Therefore, an overarching goal of an organization's social responsibility should be to contribute to sustainable development.

Hence, it is not enough to promote the corporate social responsibility, while forgetting about the social responsibility of individuals and entire societies. Social responsibility (or irresponsibility) is, last but not least, a crucial component of values with a crucial impact over the acquiring and use of knowledge and know-how. Here, the Model M project recognitions fill in a crucial leak. In the autumn of 2018, the leak was made visible, e.g. in the Marakesh conference on migration issues, the Katowice conference on climate change issues, the protests against the social injustice in several countries, about one hundred million displaced persons who are victims of the lack of social responsibility of the power holders etc., as the public media keep informing.

The basis for understanding the concept of social responsibility was Carroll's Pyramid (Carroll, 1979; Carroll \& Archie, 2015), which defined economic, legal, ethical and philanthropic responsibility. The answer to the second research question is the Model M method (MMm). This method has shown that investing in young people and their employments has a great impact on the individual, society and business. According to Caroll's Pyramid of Social Responsibilty, each person can create their own succes with economic, legal, ethical and philantropic responsibility. As young people take responsibility for their own lives and success, society becomes more responsible, too (Manual Model M Slovenia, 2018). Further research is therefore required as to individual responsibilty in the context of social responsibility.

The implications of our research for individuals, managers, society and policy makers are connected. Individuals can try to find a way to educate themselves more on the topics of social responsibility to contribute to their (self-)employment and to society. Policy makers can include social responsibility and the Model $\mathrm{M}$ method in the curriculum of education programs at all educational levels. Managers can improve their knowledge by getting a certificate on this topic from independent training providers. They can also employ young people, offering them apprenticeship and internship or a first employment. Society could improve by creating new policies to reduce youth unemployment and linking different stakeholders to build the capacities for youth's economic independence. All these topics could be further research subjects.

In the 2030 Agenda for Sustainable Development (UN, 2015), adopted by all United Nations Member States in 2015, a 
shared blueprint for peace and prosperity for people and the planet, now and into the future, is provided. At its heart are the 17 Sustainable Development Goals (SDGs), which are an urgent call for action by all countries - developed and developing - in a global partnership. They recognize that ending poverty and other deprivations must go hand-in-hand with strategies that improve health and education, reduce inequality, and spur economic growth - all while tackling climate change and working to preserve our oceans and forests. We hope that our research has made a small impact towards these changes and making the world a better place as well.

\section{Acknowledgement}

This paper has a partial background in the paper "Model M Slovenia and Its Impact on Society” by Anita Hrast, MS., Martina Rauter, Ph.D., and Monika Rajšp, B.S, presented at the 13th International Scientific Conference "Social Responsibility and Current Challenges 2018: Social Responsibility and Sustainable Development in Science, Education and Business", sponsored by the IRDO Institute for the Development of Social Responsibility (IRDO) from Maribor, Slovenia.

\section{References}

Bohinc, R. (2017). Družbena odgovornost. Univerza v Ljubljani, Fakulteta za družbene vede, Ljubljana.

Brewer, L. (2013). Enhancing youth employability: What? Why? and How? Guide to core work skills. International Labour Office, Skills and Employability Department. Geneva: ILO. Retrieved from http://www.oitcinterfor.org/sites/default/files/file_publicacion/ wcms_213452_0.pdf

Buchert, L. (2014). Learning needs and life skills for youth: An introduction. International Review of Education, 60(2), 163-176. https:// doi.org/10.1007/s11159-014-9431-3

Carroll, A. B. (2015). Corporate social responsibility: The centerpiece of competing and complementary frameworks. Organizational Dynamics, 44, 87-96. https://doi.org/10.1016/j.orgdyn.2015.02.002

Collins, J. (2005). Good to Great and the Social Sector: Why Business Thinking Is Not the Answer. New York: Mohonk.

Feldt, H., Marx, M., Benelung, N., Kirtz, L., \& Von Stamm, J. (2018). How to Bridge the Skills Gap to Promote Decent Rural (Youth) Employment. A Practioner's Guide. SLE Postgraduate Studies on International Cooperation for Sustainable Development. Berlin: Publication series S276, 2.

Folger, J. (2019). What factors go into calculating social return on investment (SROI)? Investopedia.com, 2019. Retrieved from https://www. investopedia.com/ask/answers/070314/what-factors-go-calculating-social-return-investment-sroi.asp

Government Office for Science (2017). Future of skills and lifelong learning. Government Office for Science, London, UK. Retrieved from https://assets.publishing.service.gov.uk/government/uploads/system/uploads/attachment_data/file/727776/Foresight-future-ofskills-lifelong-learning_V8.pdf

Hehenberger, L., Harling, A. M., \& Scholten, P. (2013). A Practical Guide to Measuring and Managing Impact. EVPA Knowledge Centre; in Proposed Approaches to Social Impact Measurement in European Commission legislation and in practice relating to: EuSEFs and the EaSI, GECES Sub-group on Impact Measurement, 16 February 2014 (following initial publication on 28th November 2013).

Hrast, A., Kojc, S., \& Mulej, M. (2014). Študija in model merjenja družbenih učinkov socialnih podjetij v Sloveniji (Measuring of the social effects of the social enterprises in Slovenia). Maribor: IRDO - Institute for development of social responsibility.

Hrast, A., \& Rajšp, M. (2018). Regijsko usposabljanje mladih po metodi Model M Slovenija. Model M Slovenija -Train the trainer. Priročnik za trenerje po metodi Model M Slovenija. Maribor: IRDO - Institute for development of social responsibility.

Hrast, A., Mulej, M. \& several different co-editors (2005-2018). Social Responsibility and Current Challenges. Zbirka Družbena odgovornost. Maribor: IRDO - Institute for development of social responsibility.

Hrast, A., Rauter, M., \& Rajšp, M. (2018). Model M Slovenia and its impact to society'. 13th International Scientific Conference 'Social Responsibility and current Challenges 2018: Social responsibility and sustainable development in science, education and business'. Maribor: IRDO Institute for the Development of Social Responsibility.

ILO (2019). Time to Act for SDG 8: Integrating Decent Work, Sustained Growth and Environmental Integrity. Geneva, International Labour Office. ISBN 978-92-2-133678-5 (web pdf). Retrieved from https://ilo.primo.exlibrisgroup.com/view/delivery/41ILO_ INST/1261199860002676

ISO (2010). ISO 26000:2010 - Social responsibility. Retrieved from http://www.iso.org/iso/home/standards/iso26000.htm

IYF (2014). Global partnership for youth employment. Strengthening Life Skills for Youth. A Practical Guide to Quality Programming. International Youth Foundation (IYF). Baltimore, USA. Retrieved from https://www.s4ye.org/agi/pdf/Project_Design/Strengthening_ Life_Skills_For_Youth.pdf

Lebe, S. S., Mulej, M., guest-editors \& authors, with coauthors (2014). Social responsibility and holism in tourism. Kybernetes, 43(3-4), 346-666.

Leclair, C., Dupon, A., Sibeude, T., \& Sibille, H. (2013). Petit Précis de L'evaluation de L'impact social. In Proposed Approaches to Social Impact Measurement in European Commission legislation and in practice relating to: EuSEFs and the EaSI, GECES Sub-group on Impact Measurement, 16 February 2014 (following initial publication on 28th November 2013) Retrieved from www.avise.org.

Manual Model M Slovenia (2018). Train the trainer, Results of the project Model M Slovenia: Priročnik Model M Slovenija - Train the trainer, Rezultati projekta Model M Slovenija. http://www.model-m.si/wp-content/uploads/2018/09/IRDO-Train-the-trainers-OK.pdf 
Medvedeva, T. A. \& Umpleby, S. A. (2015). A multi-disciplinary view of social and labor relations: changes in management in the U.S. and Russia as examples. Cybernetics and Systems: An International Journal, 46(8), 681-697. https://doi.org/10.1080/01969722.2015.1082405

IRDO (2018). IRDO Institute and the Model M Slovenia project internal documents, some available at www.irdo.si and www.model-m.si. Mourshed, M., Patel, J., \& Suder, K. (2014). Education to employment: Getting Europe’s youth into work. Berlin: McKinsey \& Company.

Mulej, M., \& Čagran, B. (ed.) (2016a). Uveljavljanje družbene odgovornosti v vzgoji in izobraževanju. Knjižna zbirka Nehajte sovražiti svoje otroke in vnuke, tretja knjiga. Zbirka Frontier books. Maribor: IRDO - Institute for development of social responsibility.

Mulej, M., \& Hrast, A. (ed.) (2016b). Informacije za odločanje družbeno odgovornih. Knjižna zbirka Nehajte sovražiti svoje otroke in vnuke, druga knjiga. Zbirka Frontier books. Maribor: IRDO Inštitut za razvoj družbene odgovornosti in Kulturni center Maribor,

Mulej, M., Božičnik, S., Čančer, V., Hrast, A., Jurše, K., Kajzer, Š., Knez-Riedl, J., Jere Lazanski, T., Mlakar, T., Mulej, N., Potočan, V., Risopoulos, F., Rosi, B., Steiner, G., Štrukelj, T., Uršič, D., \& Ženko, Z. (2013a). Dialectical Systems Thinking and the Law of Requisite Holism Concerning Innovation. Litchfield Park: Emergent Publications.

Mulej, M., Hrast, A., \& Dyck, R., guest editors \& authors (2015). Social responsibility - a new socio-economic order. Systems Research and Behavioral Science, 32(2), 147-214.

Mulej, M., Hrast, A., \& Ženko, Z., guest editors \& authors (2013b). Social Responsibility - measures and measurement. Systems Practice and Action Research, 26(6), 471-588. https://doi.org/10.1007/s11213-013-9297-5

Mulej, M., Hrast, A., Naterer, A, (editors) (2016c). New social realities from the view of social responsibility: newest scientific views with case studies: [conference proceedings] = Nove družbene realnosti z vidika družbene odgovornosti: novi znanstveni pogledi s primeri dobrih praks: [zbornik prispevkov], Zbirka Družbena odgovornost. Maribor: IRDO - Inštitut za razvoj družbene odgovornosti.

Mulej, M., Merhar, V., \& Žakelj, V. (ed.) (2016d). Družbeno-ekonomski okvir in osebne lastnosti družbeno odgovornih. Trilogija Nehajte sovražiti svoje otroke in vnuke, prva knjiga. Zbirka Frontier books. Maribor: IRDO - Inštitut za razvoj družbene odgovornosti in Kulturni center Maribor,

Mulej, M., Merhar, V., Žakelj, V., editors \& authors, Zore, M., Hrast, A., Slapnik, T., Rašić, K., Toplak, L., Ambrožič, B. (2019). Uvod v politično ekonomijo družbeno odgovorne družbe. Maribor: Kulturni center.

Mulej, M., Dyck, R., editors \& coauthors, with coauthors (2014). Social responsibility beyond neoliberalism and charity. 4 volumes. Betham Science, Shirjah, UAE. E-book, 33 chapters, 48 authors from 13 countries

1. SR - A Non-Technological Innovation Process

2. SR - Range of Perspectives per Topic and Countries

3. SR - Sustainability, Education and Management

4. SR - Methods, Dilemmas and Hopes

OECD (2017). OECD Economic Surveys: Slovenia 2017. Paris: OECD Publishing. https://doi.org/10.1787/eco_surveys-svn-2017-en.

OECD (2018). The future of education and skills, Education 2030. Paris: OECD. Retrieved from https://www.oecd.org/education/2030/ E2030\%20Position\%20Paper\%20(05.04.2018).pdf

OECD (2019). Youth unemployment rate (indicator). https://doi: 10.1787/c3634df7-en

Rožman, M., Shmeleva, Z., \& Tominc, P. (2019). Knowledge Management Components and Their Impact on Work Engagement of Employees. Naše gospodarstvo/Our Economy, 65(1), 40-56. https://doi.org/10.2478/ngoe-2019-0004

Stanescu, S. G. \& Comandaru, A. M. (2019). The implications of social responsibility in reducing youth unemployment in Romania. Central European Review of Economics and Management, 3(2), 33-48. http://dx.doi.org/10.29015/cerem.749

UN (2015). Transforming our world: the 2030 Agenda for Sustainable Development. 4th plenary meeting, 25 September 2015. United Nations General Assembly. Retrieved from https://www.un.org/ga/search/view_doc.asp?symbol=A/RES/70/1\&Lang=E 


\section{Razvoj metode Model M (mMM) in njen prispevek k družbeno odgovorni družbi}

\section{Izvleček}

Model M pomeni biti mlad in biti vzor drugim, kako inovativno najti zaposlitev ali ustvariti samozaposlitev ter tako postati in ostati aktiven državljan. IRDO - Inštitut za razvoj družbene odgovornosti je v letih 2012-2018 realiziral projekt Model M Slovenija. Projekt se je začel v Podravju v letih 2012-2014 z majhnim zneskom denarja, ki ga je vložila lokalna skupnost (Mestna občina Maribor). Pozneje ( $v$ letih 2016-2018) je prerasel v nacionalni projekt, ki sta ga sofinancirala Evropski socialni sklad in Republika Slovenija. Namen projekta je bil mlade opolnomočiti z usposabljanjem, mreženjem, svetovanjem in aktivno udeležbo v družbi, da bi ustvarili lastne modele uspeha. V tem prispevku predstavljamo metodo Model M (mMM), ki smo jo razvili v okviru projekta Model M Slovenija, in njen družbeni vpliv na zaposlovanje mladih v Sloveniji. Z metodo povračila - donosnosti družbene naložbe (SROI), metodo za merjenje družbenega učinka, predstavljamo, kako so bila sredstva, vložena v prvotni lokalni pilotni projekt, pozneje na nacionalni ravni v okviru projekta Model M Slovenija desetkrat pomnožena. Izvirnost metode Model M (mMM), kot je predstavljena v tem prispevku, je njen potrebni celostni pristop $\mathrm{k}$ usposabljanju mladih v smislu osebne in družbene odgovornosti. mMM pospešuje (samo)zaposlovanje mladih in drugih brezposelnih oseb. mMM je ustvarila ekipa poslovnih strokovnjakov in raziskovalcev družbene odgovornosti. Njihov cilj je bil uveljaviti in razviti družbeno odgovornost, soodvisnost in potreben celostni pristop kot sistemsko vedenje, ki ga svetovno človeštvo predlaga v svetovalnem standardu ISO 26000.

Ključne besede: projekt Model M, mladi, zaposlovanje, socialna donosnost naložb, merjenje učinka, družbena odgovornost, družbeno odgovorna družba 